

\title{
Between Popular Votes and the Electoral College: The Paradox of the American Electoral System
}

\author{
Mike Omilusi, (PhD) \\ Department of Political Sciences \\ Ekiti State University, Nigeria \\ watermike2003@yahoo.co.uk \\ $\&$
}

\section{Ajibola O. Peter Adu}

Department of General Studies

Federal Polytechnic, Ado-Ekiti

"The Electoral College is a disaster for democracy"

-Donald Trump tweet in 2012

"No principle is more fundamental to the theory of democratic governance than political equality; that is, the idea that every citizen's voice or views should count as much as anyone else's"

- Doug McAdam (2014)

\section{Abstract}

Every four years, the Electoral College, a little known feature of the American Constitution, enjoys a fleeting movement of fame. For the fifth time in U.S. history, and the second time this century, a presidential candidate won the White House while losing the popular vote. Hillary Clinton won more votes than Donald Trump in the 2016 presidential election. But due to the exigency of the Electoral College, Donald Trump became president of the United States. If, according to Timm (2016), "our supposedly 'democratic' system for picking nominees for president is terribly broken and should be dramatically overhauled", then this paper seeks to unravel the inherent contradictions in the American Presidential election. Is it an acceptable global template for liberal democracy? Are the voters not short-changed in the electoral process pertaining to their wishes and eventual outcome? This paper interrogates the American democracy within the context of popular votes and Electoral College, having the 2016 Presidential election as the primary focus. 


\section{Introduction}

Some academics have criticized the Electoral College for years. It has been called an "anachronism" that "thwarts" democratic principles, (Wildavsky, 2000 cited in Ross, 2004:2) "constitutional stupidity," (Balkin, 1995 cited in Ross, 2004:2) or even a "dangerous game" with "many built-in pitfalls" that are "bound to destroy us" Michener, 1969). The idea of using electors is from the American constitution as the nation's founding fathers saw it as a compromise between electing the president by a popular vote among citizens and electing the president in Congress. Each state in the USA has a number of electors in the Electoral College which is determined by the size of its population. For instance, California which is the most populous state in the US, has 55 electoral votes while others like Alaska and the District of Columbia have 3 votes apiece. Currently, the Electoral College has 538 electors. A candidate needs 270 electoral votes which is half of the total plus one, to win the White House race. Hillary Clinton won more votes than Donald Trump in the 2016 presidential election. But due to the magic of the Electoral College, Donald Trump will be the next president of the United States.

It is an established fact that an election is the process by which citizens select the thousands of men and women they want to run their government--at all levels. In a democracy, government officials are chosen by the people and serve for a specific time called a term of office. Thus, elections and democracy have become virtually synonymous in Western political thought and analysis (Joseph 1999). In the liberal conception, 'elections are the defining institution of democracy' (Bratton \& Posner 1999). Few textual critics, if any, can improve on Abbey Lincoln's concise definition of democracy as "government of the people, by the people, for the people". In what sounds like a derivative of that classic definition, democracy may be said to be a system of government by the majority of eligible voters of a State, typically through elected representatives; a rule by the majority; a government in which the supreme power is vested in the (majority) of the people and exercised by them directly or indirectly through a system of representation usually involving periodically held elections (Akiri, 2016).

For decades, polls have shown that large majorities of Americans would prefer a popular vote system instead of the Electoral College. For instance, a 2013 Gallup poll showed 63 percent of adults wanted to do away with it, and a mere 29 percent wanted to keep it. (However, 
these margins have tightened since the 2016 election.) But to ditch the Electoral College entirely, the US would have to pass a constitutional amendment (passed by two-thirds of the House and Senate and approved by 38 states) -or convene a constitutional convention (which has never been done, but would have to be called for by 34 states). Either method is vanishingly unlikely, because each would require many small states to approve a change that would reduce their influence on the presidential outcome (Prokop, 2016).

If, according to Timm (2016), "our supposedly "democratic" system for picking nominees for president is terribly broken and should be dramatically overhauled", then this paper seeks to unravel the inherent contradictions in the American Presidential election. Is it an acceptable global template for liberal democracy? Are the voters not short-changed in the electoral process pertaining to their wishes and eventual outcome? It is in this light that this paper interrogates the American democracy within the context of popular votes and Electoral College, having the 2016 Presidential election as primary focus.

\section{Democracy and American Electoral System: Background Information}

No political parties officially existed when the U.S. Constitution was written in the late 1780s. The founders of the country actually felt that political parties were not a good thing and that they would divide people against each other and harm the democracy. However within 10 years after the Constitution was written, the U.S. had two major political parties--the Federalist party that was a proponent of a strong central government--and the Democratic-Republican party (also called the Anti-Federalist Party) that supported strong state governments. The Democratic- Republican Party eventually became known as the Democratic Party. The Whig party developed in the 1830s in opposition to President Andrew Jackson and his policies. The Whig party eventually split apart, mainly over the issue of slavery. Proslavery Whigs re-joined the Democratic Party and many antislavery Whigs formed a new party in 1854 called the Republican Party. Abraham Lincoln was the first Republican president.

Today, the Democrats and Republicans remain the two leading parties in our country. However, there are other political parties such as the Independent Party, the Reform Party, the 
Libertarian Party, the Green Party, the Socialist Party, the Populist Party, and others (Utah Education Network, n.d).

Departing from the monarchical tradition of Britain, the founding fathers of the United States created a system in which the American people had the power and responsibility to select their leader. Under this new order, George Washington, the first U.S. president, was elected in 1789. At the time, only white men who owned property could vote, but the 15th, 19th and 26th Amendments to the Constitution have since expanded the right of suffrage to all citizens over 18. Taking place every four years, presidential campaigns and elections have evolved into a series of fiercely fought, and sometimes controversial, contests, now played out in the 24-hour news cycle.

Unlike in most industrial democracies, voters in America do not directly choose a presidential candidate, but rather vote for representatives to the Electoral College, the body that formally selects the new president and vice president. This fact is often lost on voters, who may be only dimly aware of the Electoral College's existence. The College exists only for one day following the election and never meets as a unified body; each state's electors meet separately in their own capital on the first Monday after the second Wednesday in December following a presidential election and send their votes to Congress separately. Electors are obligated but not technically bound to vote for the candidate who wins a plurality of the popular vote in their state (a tiny percentage have been unfaithful to their "instructions" and many states have penalties for violating a pledge) (Warf, 2008).

The presidential election is held every four years on the Tuesday after the first Monday in November. You help choose your state's electors when you vote for President because when you vote for your candidate you are actually voting for your candidate's electors. According to Chris Akiri (2016), "the political structure in the United States of America, where the emergence of the President and Vice-President depends on a so-called Electoral College, established by Article Two of the United States Constitution (1787), whereby the voice of the majority (popular vote) is bridled by a political artifice called Electoral College Vote is the very antithesis of "government of the people, by the people, for the people" and can, therefore, not be dignified with the name of democracy". As noted by Andrew Prokop (2016):

The presidential election is generally portrayed as a battle to win states and their accompanying electoral votes. Hillary Clinton won Vermont, so she got its three electoral votes. Donald Trump won Alaska, so he got its three electoral votes. Whoever gets to 270 or more electoral votes first - 
a majority of the 538 total — wins the election. What's happening under the hood, though, is more complicated. When people go to the polls to vote for a presidential candidate, what they are actually doing is voting for each party's nominated slate of electors in their respective states (or, in the case of Maine and Nebraska, in congressional districts too).

Theories of majoritarian electoral democracy, as positive or empirical theories, attribute U.S. government policies chiefly to the collective will of average citizens, who are seen as empowered by democratic elections (Gilens and Page, 2016). However, the impacts of individuals and groups of voters on national elections in the United States have been the object of enormous popular and academic scrutiny, in part because the forces that shape this phenomenon are institutionalized in highly uneven ways geographically through the Electoral College. This topic is richly deserving of the attention of anyone interested in the dynamics of American politics and the ways in which democratic politics are constituted over time and space (Warf, 2008).

It should be stated that America's democratic claims are reinforced by the strict separation of powers that is stipulated in the Constitution. The Executive has no direct influence in Congress, Congress has no power over the Executive, and the Judiciary has no power over either, and cannot be influenced by either. Because of this, there is no chance for a President to form a dictatorship.

\section{Between Popular Vote and Electoral College: Delicate Electoral Outcomes in History}

The US president is not directly chosen by voters, but by 'electors' that people in a state vote for. The more people in a state, the more electors an area has. For example, Texas has a population of 25 million and is afforded 38 Electoral College votes, while Delaware has a population of 936,000 and has only three votes. There are 538 electors in total, corresponding to 435 members of Congress, 100 Senators and three additional electors for the District of Columbia. They will meet in their respective states on 19 December to ultimately elect the President. Almost every state chooses to allocate all its Electoral College votes to whoever comes in first place state-wide, regardless of their margin of victory. Whoever gets to 270 
electoral votes first - the majority of the 578 total votes - wins the election. And this time it was Mr Trump.

The Electoral College is a process, not a place. The founding fathers established it in the Constitution as a compromise between election of the President by a vote in Congress and election of the President by a popular vote of qualified citizens. The Electoral College process consists of the selection of the electors, the meeting of the electors where they vote for President and Vice President, and the counting of the electoral votes by Congress. The Electoral College consists of 538 electors. A majority of 270 electoral votes is required to elect the President. Your state's entitled allotment of electors equals the number of members in its Congressional delegation: one for each member in the House of Representatives plus two for your Senators. Read more about the allocation of electoral votes. States are not allotted electoral votes solely based on population. They are given electoral votes based on their representation in Congress. So each state is given a minimum of 3 electoral votes (each state has 2 Senators and at least 1 Representative) regardless of population.

Each candidate running for President in your state has his or her own group of electors. The electors are generally chosen by the candidate's political party, but state laws vary on how the electors are selected and what their responsibilities are. Read more about the qualifications of the Electors and restrictions on who the Electors may vote for. The presidential election is generally portrayed as a battle to win states and their accompanying electoral votes. For instance, Hillary Clinton won Vermont, so she got its three electoral votes. Donald Trump won Alaska, so he got its three electoral votes. Whoever gets to 270 or more electoral votes first a majority of the 538 total - wins the election. So rather simply trying to win the most actual votes in the country, a presidential campaign must try to put together a map of state victories that will amass more than 270 electoral votes. That is the simplified version (Prokop, 2016).

The system would be correct if in each state one would elect a number of electors proportionate to its population, but it is not that way. For example, Wyoming has a population of 500,000 people and 3 electoral votes, in other words, each electoral vote represents 166,000 people whereas California has a population of 34 million people and 55 electoral votes, therefore each vote represents 600,000 people. Because of this, the vote of a Californian is worth four times less than the vote of a Wyomingite (Sáenz, 2016). In other words, not all "American citizens" are equal because the votes of some are worth more than those of others. 
Even worse, the electoral votes of each state are not distributed proportionately according to the popular votes that each presidential candidate obtains but instead, with the exception of Maine and Nebraska, the candidate that receives more popular votes gets all the electoral votes of the state (Sáenz, 2016).

Candidates identify the states that are safely either Republican or Democrat - the ones they are bound to lose or win - and broadly ignore these in their campaign efforts. Instead, they focus their attentions on the states that tend to swing between the two parties. This means that, arguably, the election is decided not by the nation as whole but by a small number of so-called battleground states. Two-thirds (273 out of 399) of campaign events in the 2016 election were held in only six states (Florida, North Carolina, Pennsylvania, Ohio, Virginia and Michigan). The Electoral College system, as observed by Trueman (2018), distorts public opinion. All the Electoral College votes for a particular state go to the candidate who received the most votes in that state, even if it was $50.5 \%$ to $49.5 \%$. In this way the election results do not truly reflect public opinion, which really doesn't aid American democracy.

The Constitution is silent on how a state is to choose its electors. In the early years, legislatures adopted several methods: appointment by legislature, election by the people on the state-wide basis, or a combination of these methods. But by 1836, almost every state was using a popular vote system (League of Women Voters Education Fund, 1980). On Election Day, when voters in each state go to the polls, each one casts a ballot for the slate of presidential electors who are pledged to support the candidate the voter prefers. These slates have been selected by political parties, through conventions, committees or primaries. When a candidate is not a nominee of a party, the slate is named through a petition filed with the required number of signatures. In some states, only the names of the presidential and vice-presidential candidates appear on the ballot, masking the fact that voters are choosing electors rather than voting directly for the candidates. In the other states, both candidates and electors are identified (League of Women Voters Education Fund, 1980).

The 2016 presidential election in America made Trump the fifth President to lose the popular vote but win his spurs against his opponent. In 1876, Republican Rutherford B. Hayes, with 4,036,298 popular votes, won 185 Electoral College votes. His opponent, Democrat Samuel J. Tilden, won the popular vote with 4,300,590 votes, but won only 184 Electoral College votes. Hayes was elected President. In 1888, Benjamin Harrison, with 5,439,853 
popular votes, won 233 Electoral College votes. His main sopponent, Democrat Grover Cleveland, won the popular vote with 5,540,309 votes, but won only 168 Electoral College Vote. Harrison was elected President. In 2000, Republican George W. Bush garnered only 50,456,062, and his main opponent, Democrat Al Gore, got 50,996,582 popular votes. Even so, Bush became President as he polled 271 Electoral College votes to Al Gore's 266. Usually and almost ineluctably, candidates that lose the popular vote but become Presidents via that load of hocus pocus called "Electoral College Vote" turn out to be particularly unsuccessful and unpopular Presidents! It is strange that all the beneficiaries of the Electoral College Vote peculation have been Republicans (Akiri, 2016).

In the 2016 Electoral College balloting, Donald Trump won 304 electoral votes to Hillary Clinton's 227, with five Democratic and two Republican "faithless electors" voting for other people. That result was despite the fact that Clinton received nearly 2.9 million more popular votes than Trump in November's election, according to Pew Research Center's tabulation of state election results. Our tally shows Clinton won 65.8 million votes (48.25\%) to almost 63 million $(46.15 \%)$ for Trump, with minor-party and independent candidates taking the rest (DeSilver, 2016). This mismatch between the electoral and popular votes, as aptly observed by DeSilver (2016), came about because Trump won several large states (such as Florida, Pennsylvania and Wisconsin) by very narrow margins, gaining all their electoral votes in the process, even as Clinton claimed other large states (such as California, Illinois and New York) by much wider margins. Trump's share of the popular vote, in fact, was the seventh-smallest winning percentage since 1828 , when presidential campaigns began to resemble those of today ones.

However, as Ross (2004) argues, contrary to modern perceptions, the founding generation did not intend to create a direct democracy. To the contrary, the Founders deliberately created a republic -- or, arguably, a republican democracy -- that would incorporate a spirit of compromise and deliberation into decision-making. Such a form of government, the Founders believed, would allow them to achieve two potentially conflicting objectives: avoiding the "tyranny of the majority" inherent in pure democratic systems, while allowing the "sense of the people" to be reflected in the new American government. Ross notes further: 
federalism, prevents chaos, grants definitive electoral outcomes, and prevents tyrannical or unreasonable rule. The Founding Fathers created a stable, well-planned and carefully designed system -- and it works. Past elections, even the elections of Presidents who lost the popular vote, are testaments to the ingenuity of the Founding Fathers. In each case, the victor was able to succeed only because his opponent did not build the national coalition that is required by the Electoral College. In each case, smaller states were protected from their larger neighbors. In each case, the presidential election system functioned effectively to give the country a President with broadbased support.

The Electoral College has been the subject of much discussion over the years. Opponents of the college call it undemocratic. They say it functions in contradiction to the oneperson, one-vote principle, by giving each state at least three votes, even though on a straight population basis, some states might be entitled to only one or two. If the choice of President goes to the House of Representatives, where each state has only one vote, the election becomes even further removed from the equality-of-population principle. These critics point out that in a contingent election, the single representative from the least populous state has a vote that carries 54 times more weight than that of a representative from the state of California, the most populous state, with the largest number of representatives. There are seven states with only one representative.

For most of its inauspicious history, the Electoral College has been regarded as a quirky peculiarity of US politics, with few Americans understanding its role or what it does, and even fewer foreigners seeing any sense in it. The creation of the Electoral College, as posited by Cranston (2016) tells its own story about the formation of modern America, and its embrace of independence from colonial rule:

\footnotetext{
When confronted with the task of creating a government for their newly independent sovereign nation, America's so-called "Founding Fathers" were very distrustful of foreign intervention in their government. They wished not to see a return to colonial enslavement, so ensured that their Constitution prohibited non natural-born citizens assuming the presidency. They wanted to ensure that only an American would govern Americans.
} 
On election day, whichever political party's candidate, be it Republican, Democratic or a third party, wins the majority of the state's votes, that slate of electors becomes the ones who get to vote for the president in their respective state. For example, in 2012, Californians voted for the 55 party-selected Democrats who in turn all cast their 55 votes for the Obama/Biden ticket. Donald Trump won because of the Electoral College system - a much maligned and complex way of determining the future leader of America. For critics of the Electoral College, the Achilles heel of the College is its ability to select a President that fails to win the popular vote. Moreover, and as a direct result of the close presidential elections in the last forty years, many students of the Electoral College have continually warned that the College would soon "malfunction" by producing a minority President.

\section{Can Alternative Emerge in Future Electoral Reform?}

The political structure in the United States of America, where the emergence of the President and Vice-President depends on a so-called Electoral College, established by Article Two of the United States Constitution (1787), whereby the voice of the majority (or popular vote) is bridled by a political artifice called Electoral College Vote is the very antithesis of "government of the people, by the people, for the people" and can, therefore, not be dignified with the name of democracy, and America cannot, ipso facto, claim to be the "greatest democracy on earth" (Akiri, 2016). The outcome of a presidential election in the U.S. is really just settled in a few so-called swing States. Today, only 12 of the 50 States in the U.S. control about 53 per cent of the votes in the Electoral College (Akiri, 2016). In its editorial, The New York Times (2016) asserts that:

By overwhelming majorities, Americans would prefer to elect the president by direct popular vote, not filtered through the antiquated mechanism of the Electoral College. They understand, on a gut level, the basic fairness of awarding the nation's highest office on the same basis as every other elected office to the person who gets the most votes.

From the foregoing, it becomes obvious that the Electoral College system creates the possibility for the loser of the popular vote to win the electoral vote. This is more than a 
theoretical possibility. It has happened at least five times out of the 57 presidential elections, or more than 7 percent of the time, which is not such a small percentage (Black, 2012). The Founding Fathers' concerns with direct popular elections have mostly vanished. The national political parties have been around for years. Travel and communication are no longer problems. The public has access to every word spoken by every candidate every day. These changes have led to calls for reforms to the system (Longley, 2019). A wide variety of constitutional proposals to reform presidential election procedures have been introduced over time.

Proponents of presidential election reform generally advocate either completely eliminating the electoral college system, replacing it with direct popular election, or repairing perceived defects in the existing system. The direct election alternative would replace the electoral college with a single, nationwide count of popular votes. That is, the candidates winning a plurality of votes would be elected; most proposals provide for a runoff election if no candidates received a minimum of $40 \%$ of the popular vote (Whitaker and Neale, 2004). Proponents of direct popular election cite a number of factors in support of the concept. At the core of their arguments, they assert that the process would be simple, national, and democratic (Neale, 2009).

Electoral college reform proposals include (1) the district plan, awarding each state's two at-large electoral votes to the state-wide popular vote winners, and one electoral vote to the winning candidates in each congressional district; (2) the proportional plan, awarding electoral votes in states in direct proportion to the popular vote gained in the state by each candidate; and (3) the automatic plan, awarding all of each state's electoral votes directly on a winner-take-all basis to the state-wide vote winners. Major reforms of the system can be effected only by constitutional amendment, a process that requires two-thirds approval by both houses of Congress, followed by ratification by three-fourths (38) of the states, usually within a period of seven years (Whitaker and Neale, 2004).

Also, instant runoff voting (IRV) could be used for Presidential elections with or without the Electoral College. Instant runoff voting on a national scale has the potential to solve many of the current dilemmas introduced by the Electoral College as well as the problems introduced by some of the other alternatives. It would end the spoiler dynamic of third party and independent candidates and consistently produce a majority, nationwide winner. With a direct vote, voters would rank their preferences rather than marking only one candidate. Then, 
when the votes are counted, if no single candidate has a majority, the candidate with the lowest number of votes is eliminated. The ballots are then counted again, this time tallying the second choice votes from those ballots indicating the eliminated candidate as the first choice. The process is repeated until a candidate receives a majority, reducing time and money wasted in a normal runoff election. Individual states can also adopt instant runoffs without a Constitutional amendment.

Another apparent trend is that recent reform proposals go beyond the concept of simply substituting direct election for the electoral college (Neale, 2009). In recent Congresses, such amendments have been more likely to include provisions that would enhance and extend the power of the federal government to legislate in such areas as residence standards, definition of citizenship, national voter registration, inclusion of U.S. dependencies in the presidential election process, establishment of an election day holiday, ballot access standards for parties and candidates, etc. (Neale, 2009). This trend, it may be posited, arguably reflects frustration on the part of many voters and their elected representatives over the uncertainties and inconsistencies in local election administration procedures.

\section{Conclusion}

Over the years, some of those who basically support the Electoral College system, as well as those who think it works badly, have suggested changes in the system by which Americans elect their President. In recent decades, the most widely offered proposal to reform the present method of electing the President and Vice President has been the direct election plan. Under this plan, the electoral college would be abolished, and the President and Vice President would be elected directly by popular vote. For Cranston (2016), "the ratification by the Electoral College confirms that the United States can no longer refer to itself as the world's greatest democracy". For many, the idea that you can have the most people vote for you but still lose the election seems undemocratic. This has happened five times in the US history. The fact that Mr Trump won several key swing states very narrowly, while Mrs Clinton won big majorities in some states is part of the reason she was able to get more votes but still lost the election. 


\section{References}

Akiri, Chris (2016) America's Electoral College and Democracy, Available at: http://www.nigeriatoday.ng/2016/11/americas-electoral-college-anddemocracy/

Akiri, Chris (2016) America's Electoral College: Enemy of democracy, The Guardian, November 28

Black, Eric (2012) 10 reasons why the Electoral College is a problem, MinnPost, October 16 Bratton, M \& Posner, D.N (1999) 'A First Look at Second Elections in Africa with Illustrations from Zambia'. In R Joseph (ed) State, Conflict and Democracy in Africa. Boulder and London: Lynne Rienner Publishers.

Cranston, Bryan (2016) Electoral College has failed America and democracy in electing Donald Trump, Independent, 20 December

DeSilver, Drew (2016) Trump's victory another example of how Electoral College wins are bigger than popular vote ones, Pew Research Center, December 20

Gilens, Martin and Page, Benjamin I. (2014) Testing Theories of American Politics: Elites, Interest Groups, and Average Citizens, Perspectives on Politics, September 2014 | Vol. 12/No. 3

Joseph, R. (1999) 'State, Conflict and Democracy in Africa'. In R Joseph (ed). State, League of Women Voters Education Fund (1980) Who Will Elect the President? The Electoral College System, Available at: https://www.lwv.org/educating-voters/who-will-elect-president-electoralcollege-system

Longley, Robert (2019) How The U.S. Electoral College System Works, Available at: https://www.thoughtco.com/how-the-us-electoral-college-works-3322061

Michener, James A. (1969) Presidential Lottery: The Reckless Gamble in Our Electoral System, Conflict and Democracy in Africa, Boulder and London: Lynne Rienner Publishers

Neale, Thomas (2009) Electoral College Reform: 111th Congress Proposals and Other Current Developments, CRS Report for Congress, https://fas.org/sgp/crs/misc/R40895.pdf

Prokop, Andrew (2016) Why the Electoral College is the absolute worst, explained, Available at: http://www.vox.com/policy-andpolitics/2016/11/7/12315574/electoral-college-explained-presidentialelections-2016

Ross, Tara (2004) The Electoral College: Enlightened Democracy, Legal Memorandum, The Heritage Foundation, No 15, November 1

Sáenz, Adolfo Miranda (2016) The Electoral System of the United States Is Not Democratic, Available at: http://watchingamerica.com/WA/2016/11/25/the-electoralsystem-of-the-united-states-is-not-democratic/

The New York Times (2016) Time to End the Electoral College, December 19

Timm, Trevor (2016) America's voting system is broken. It's time to overhaul it, The Guardian, June 8

Trueman, C.N (2018) "Which Is More Democratic? America Or Britain?" historylearningsite.co.uk. The History Learning Site, 27 Mar 2015. 13 April 
Utah Education Network (n.d) United States Electoral Process, Available at: http://www.uen.org/themepark/liberty/electoralprocess.shtml

Warf, Barney (2008) The U.S. Electoral College and Spatial Biases in Voter Power, Annals of the Association of American Geographers, Volume 99, 2009 - Issue 1

Whitaker, L.P. and Neale, T. H (2004) The Electoral College: An Overview and Analysis of Reform Proposals, Available

https://www.everycrsreport.com/reports/RL30804.html 